\title{
The Impact of Silicon on Growth and Fruiting of Zaghloul Date Palms
}

\author{
Amr M. E. Haikal
}

Hort. Dept. Fac. of Agric. Damanhour Univ. Egypt

Email: amrhaika115@gmail.com

Received on: 5/6/2017

Accepted for publication on: 11/6/2017

\section{Abstract}

This study was carried out during 2015 and 2016 seasons to investigate the effect of different concentrations $(0.05,0.1$ and $0.2 \%)$ and frequencies of application of (once, twice or thrice) potassium silicate on vegetative growth aspects and nutrients in the leaves as well as yield and fruit quality of Zaghloul date palms. Randomized complete block design was adopted.

Treating the palms once, twice or thrice with potassium silicate at 0.05 to $0.2 \%$ had an announced effect on improving all growth traits, leaf chemical components, bunch weight, yield and fruit quality over the check treatment. The promotion on these parameters was in proportional to the increase in concentrations and frequencies of application. Meaningless improvement on these parameters was recorded among the higher two concentrations $(0.1 \& 0.2 \%)$ and frequencies of application (twice \& thrice).

For improving yield and fruit quality of Zaghloul date palms, it is necessary to spray the palms twice before hand pollination and again just after fruit setting with potassium silicate at $0.1 \%$.

Keywords: Zaghloul date palms, silicon, concentrations, frequencies of application, yield, fruit quality.

\section{Introduction}

More efforts have been established to improve the production of Zaghloul date palms grown under Behera environmental conditions by using new cultural practices especially silicon nutrition. Silicon is necessary for fruit crops species especially those grown under sandy soil, since it enhances the tolerance of these crops to salinity and drought. Previous studies showed that using silicon was beneficial for alleviating the unfavorable effects of all stresses on the production. It is also responsible for enhancing photosynthesis process, cell division and water uptake. It is an important antioxidant prevents the adverse effects of reactive oxygen species (ROS) from destroying plant cells. (Epstein, 1999;
Mengel et al., 2001; Alvarez and Datnoff, 2001; Aziz et al., 2002; Kanto, 2002; Ma, 2004, Hattori et al., 2005 and Marshner, 2012).

Silicon nutrition is very essential for stimulating growth aspects, nutritional status of the trees, yield and both physical and chemical characteristics of the fruits of date palms (Al-Wasfy, 2013; Ahmed et al., 2013; Gad El- Kareem, 2012 and Badran, 2016) as well as Abdelaal and Oraby-Mona, (2013) on Ewaise mangos; Ibrahim and Al-Wasfy, (2014) on Valencia oranges; ElKhawaga and Mansour, (2014) on Navel oranges; Aly, (2015) on Balady mandarins; Mohamed et al., (2015) and Abd El-Wahab, (2015) on Succary mangoes and Mahmoud, (2016) on Balady mandarins. 
The goal of this study was examining the effect of various concentrations and frequencies of application of potassium silicate on fruiting of Zaghloul date palms. Adjusting the optimum concentration and frequency of application of potassium silicate for improving yield is considered another target.

\section{Materials and Methods}

This study was carried out 2015 and 2016 seasons in a private orchard situated at Rashid city, Behera Governorate on thirty 11-years old Zaghloul date palms. Soil texture is sandy and the palms are planted at 6 x 6 meters apart. The selected palms were irrigated through surface system. Pruning was carried out to maintain leaf bunch ratio at 8:1. Number of female spathes per each palm was adjusted to ten spathes. Artificial pollination was achieved by inserting five male strands into the female bunch using known high activity pollen source throughout 2-3 days after female spathe cracking followed by bagging. Each selected palm received the common horticultural practices that are already applied in the orchard except those dealing with the application of potassium silicate.

Table 1. Analysis of the tested soil (according to Wilde et al., 1985)

\begin{tabular}{|l|c|}
\hline \multicolumn{1}{|c|}{ Content } & Value \\
\hline Sand \% & 80.0 \\
\hline Silt \% & 14.0 \\
\hline Clay\% & 6.0 \\
\hline Texture & Sandy \\
\hline O.M. \% & 0.25 \\
\hline pH ( 1: 2.5 extract) & 7.6 \\
\hline EC ( 1: 2.5 extract) dsm $\left.{ }^{-1}\right)$ & 1.00 \\
\hline Calcium carbonate \% & 4.1 \\
\hline Total N\% & 0.03 \\
\hline Available P ( Olsen, ppm) & 1.2 \\
\hline Available K ( ammonium acetate, ppm) & 15.0 \\
\hline EDTA extractable micronutrients (ppm) & \\
\hline Fe & 0.5 \\
\hline Mn & 0.4 \\
\hline Zn & 0.5 \\
\hline Cu & 0.2 \\
\hline
\end{tabular}

This experiment included the following ten treatments:

1. Control (unsprayed with water palms).

2. Spraying potassium silicate once two weeks beforehand pollination (last week of Feb.) at $0.05 \%$.
3. Spraying potassium silicate twice two weeks hand pollination and again just after fruit setting (middle of April) at $0.05 \%$.

4. Spraying potassium silicate thrice as previously mentioned dates and at one month later at $0.05 \%$. 
5. Spraying potassium silicate once as previously mentioned at $0.1 \%$.

6. Spraying potassium silicate twice as previously mentioned at $0.1 \%$.

7. Spraying potassium silicate thrice as previously mentioned at $0.1 \%$.

8. Spraying potassium silicate once as previously mentioned at $0.2 \%$.

9. Spraying potassium silicate twice as previously mentioned at $0.2 \%$.

10. Spraying potassium silicate thrice as previously mentioned at $0.2 \%$.

Each treatment was replicated three times, one palms per each. Therefore, the total uniform in vigour palms that selected to achieve this experiment was 30 palms. Triton B as a wetting agent was added to all solutions at $0.05 \%$ and spraying was done till runoff (10-20 L/tree according to the date of spraying). Randomized complete block design (RCBD) was adopted.

During both seasons, the following parameters were measured:

1. Vegetative growth aspects namely leaflet area, number of leaflet/leaf, leaf area $(\mathrm{cm})^{2}$, number of spine/leaf, length of spine $(\mathrm{cm})$ and total surface area/palm (Ahmed and Morsy, 1999).

2. Leaf pigments namely chlorophylls a \& b, total chlorophylls and total carotenoids $(\mathrm{mg} / 100 \mathrm{gF} . \mathrm{W})$ (Von-Wettstine, 1957).

3. Percentages of $\mathrm{N}, \mathrm{P}, \mathrm{K}$ and $\mathrm{Mg}$ in the driedleavesaccording to (Cottenie et al., 1982; Summer, 1985 and Wilde et al., 1985).

4. Bunch weight (kg.).

5. Yield/ palm (kg.) at the first week of September. (By multiplying number of bunches by bunch weight)
6. Some physical and chemical characteristics of the fruits namely weight (g.) and dimensions (length and width, cm.) as well as percentages of pulp and seeds, pulp/seed was also calculated, total soluble solids $\%$, total reducing and non-reducing sugars \% (A.O.A.C, 1995), total acidity (as g malic acid/100g pulp) accordingfiber crude $\%$ and total solubletannins\% (A.O.A.C, 2000).

All the obtained data were tabulated and subjected to the proper statistical analysis according to Gomez and Gomez, (1984) and New L.S.D. test at 5\% was used to differentiate among the various treatment means.

\section{Results and Discussion}

\section{1- Vegetative growth aspects:}

It is noticed from the data in Table (2) that treating Zaghloul date palms once (beforehand pollination), twice (beforehand pollination and again just after fruit setting) or thrice (beforehand pollination, just after fruit setting and at one month later) with potassium silicate at 0.05 to $0.2 \%$ significantly stimulated the six growth aspects namely leaflet area, number of leaflet per leaf, leaf area, total surface area per palm, number of spines/ leaf and spine length relative to the control treatment. A gradual stimulation on these growth parameters was observed with increasing concentrations from 0.05 to $0.2 \%$ and frequencies of application from once to thrice of potassium silicate. Increasing concentrations from 0.1 to $0.2 \%$ and frequencies of application from twice to thrice failed significantly to show any promotion on these growth traits. The maximum values were recorded on the palms that received three sprays of potas- 
sium silicate at $0.2 \%$. The lowest values were recorded on the untreated palms. There results were true during both seasons.

\section{2- Leaf chemical components:}

It can be stated from the data in Tables $(3 \& 4)$ that spraying potassium silicate once, twice or thrice at 0.05 to $0.2 \%$ significantly enhanced chlorophylls a \& b, total chlorophylls, total carotenoids, N, P, K, Mg, Ca, S, Zn and $\mathrm{Fe}$ in the leaves over the control treatment. The promotion was related to the increase in concentrations and frequencies of applications. Significant differences on these pigments and nutrients were observed among all concentrations and frequencies of application except among the higher two concentrations $(0.1 \& 0.2 \%)$ and frequencies of application (twice or thrice). Treating the palms with potassium silicate at $0.2 \%$ thrice gave the maximum values. The untreated palms produced the lowest values. These results were true during both seasons.

\section{3- Bunch weight and yield/palm:}

It is clear from the data in Table (5) that bunch weight and yield/palm were significantly improved in response to applications of potassium silicate at 0.05 to $0.2 \%$ once, twice or thrice rather than non- application. There was a gradual promotion on bunch weight and yield per palm with increasing concentrations and frequencies of applications. No significant promotion on bunch weight and yield/palm was observed among the higher two concentrations $(0.1 \&$ $0.2 \%$ ) and frequencies of application (twice or thrice). Therefore, from economical point of view, it is sug- gested to use potassium silicate twice at $0.1 \%$. Under such promised treatment, yield during both seasons reached $129 \& 130 \mathrm{~kg} / \mathrm{palm}$, respectively. The untreated palms produced $100 \& 101 \mathrm{~kg}$ during 2015 and 2016 seasons, respectively. The percentage of increment on the yield due to using the previous promised treatment over the control treatment reached 29.0 and 28.7 during both seasons, respectively.

4- Physical and chemical characteristics of the fruits:

It is evident from the datain Tables (5 to 7) that subjecting Zaghloul date palms once, twice or thrice with potassium silicate at 0.05 to $0.2 \%$ had significant effect on promoting fruit quality in terms of increasing fruit weight and dimensions (height and diameter) pulp \%, pulp/ seed, T.S.S. $\%$, total and reducing sugars $\%$ and decreasing seed weight $\%$, total acidity $\%$, total fiber $\%$ and total soluble tannins \% over the check treatment.the promotion on fruit quality was associated with increasing concentrations and frequencies of application. Meaningless promotion on fruit quality was recorded with increasing concentrations from 0.1 to $0.2 \%$ and frequencies of application from twice to thrice. Thereby, from economical point of view, it is preferable to use potassium silicate twice at $0.1 \%$ for producing good quality fruits. The untreated tree gave unacceptable effect on fruit quality. Theseresults were true during both seasons.

\section{Discussion:}

The outstanding effect of silicon on growth and fruiting of Zaghloul date palms might be attributed to its 
positive action on enhancing the tolerance of the plants to all stresses namely biotic and abiotic (drought, salinity, diseases, insects, cold, higher temperature) as well as cell division, photosynthesis and water uptake. The effect of silicon as an antioxidant that responsible for preventing the adverse effects of reactive oxygen species (ROS) on cells is not neglect in this connection (Mengel et al., 2001; Ma and Takahashi, 2002; Ma, 2004; Hattori et al., 2005 and Marschner, 2012).

The present promoting effect of silicon on growth, nutritional status of the trees, fruit retention, yield and fruit quality was supported by the results of Gad El-Kareem, (2012); AlWasfy, (2013); Abdelaal and OrabyMona, (2013); Ibrahim and AlWasfy, (2014); El-Khawaga and Mansour, (2014); Aly, (2015); Mohamed et al., (2015); Abd El-Wahab, (2015) and Mahmoud, (2016).

\section{Conclusion:}

Carrying out two sprays of potassium silicate (two weeks beforehand pollination and again just after fruit setting) at $0.1 \%$ gave the best results with regard to yield and fruit quality of Zaghloul date palms.

Table 2. Effect of different concentrations and application frequencies of potassium silicate on some vegetative growth characteristics of Zaghloul date palms during 2015 and 2016 seasons.

\begin{tabular}{|c|c|c|c|c|c|c|c|c|c|c|c|c|}
\hline \multirow[t]{2}{*}{ Treatment } & \multicolumn{2}{|c|}{$\begin{array}{l}\text { Leaflet } \\
\text { area } \\
(\mathbf{c m})^{2}\end{array}$} & \multicolumn{2}{|c|}{$\begin{array}{c}\text { No. of leaf- } \\
\text { let/leaf }\end{array}$} & \multicolumn{2}{|c|}{$\begin{array}{c}\text { Leaf area } \\
(\mathrm{m})^{2}\end{array}$} & \multicolumn{2}{|c|}{$\begin{array}{c}\text { No. of } \\
\text { spines/leaf }\end{array}$} & \multicolumn{2}{|c|}{$\begin{array}{c}\text { Spine } \\
\text { length } \\
(\mathrm{cm})\end{array}$} & \multicolumn{2}{|c|}{$\begin{array}{l}\text { Total surface } \\
\text { area/palm } \mathbf{m}^{2}\end{array}$} \\
\hline & 2015 & 2016 & 2015 & 2016 & 2015 & & 2 & 2016 & 2015 & 2016 & 015 & 201 \\
\hline & 59.1 & 58.8 & & & & & & & & & & \\
\hline & 59.9 & 59.3 & & & & & & & 0.5 & & & 0 \\
\hline & 61.4 & 60.7 & & & 1.00 & & & & 21.0 & 21 & 100.0 & 00.0 \\
\hline & 61.6 & & & & & & & & .1 & & & 01.0 \\
\hline & 61. & & & & & & & & & & & \\
\hline & 62.4 & 62.3 & & & 1.10 & & & & 2.7 & 23.5 & 110.0 & 110.0 \\
\hline 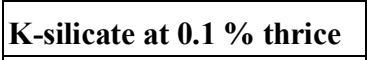 & 62.5 & 62.4 & 17 & 17 & 1.10 & 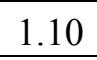 & & 3 & 2.8 & 23.6 & 110.0 & 110.0 \\
\hline & 61. & 66.0 & & & 1.06 & & & 36.0 & 22.2 & 22.8 & 106.0 & 108 \\
\hline & 62.5 & 62.4 & 176.0 & 178.0 & 1.10 & & & & 22.9 & 23.6 & 110.0 & 111.0 \\
\hline & 62.6 & 62.5 & 176.0 & 179.0 & 1.10 & & 37.0 & 38.6 & 22.9 & 23.7 & 110.0 & 112.0 \\
\hline New L.S.D a & 0.3 & 0.3 & 1.2 & 1.1 & 0.02 & 0.02 & 1.0 & 1.0 & 0.4 & 0.4 & 2.0 & 2.0 \\
\hline
\end{tabular}


Table 3. Effect of different concentrations and application frequencies of potassium silicate on leaf pigments and percentages of $N$ and $P$ in the leaves of Zaghloul date palms during 2015 and 2016 seasons.

\begin{tabular}{|c|c|c|c|c|c|c|c|c|c|c|c|c|}
\hline \multirow[t]{2}{*}{ Treatment } & \multicolumn{2}{|c|}{$\begin{array}{l}\text { Chlorophyll a } \\
\text { (mg/100gF.W) }\end{array}$} & \multicolumn{2}{|c|}{$\begin{array}{l}\text { Chlorophyll b } \\
\text { (mg/100gF.W) }\end{array}$} & \multicolumn{2}{|c|}{$\begin{array}{c}\text { Total } \\
\text { chlorophylls } \\
\text { (mg/100gF.W) }\end{array}$} & \multicolumn{2}{|c|}{$\begin{array}{c}\text { Total } \\
\text { carotenoids } \\
\text { (mg/100gF.W) }\end{array}$} & \multicolumn{2}{|c|}{$\begin{array}{c}\text { Leaf N } \\
\%\end{array}$} & \multicolumn{2}{|c|}{$\begin{array}{c}\text { Leaf } P \\
\%\end{array}$} \\
\hline & 2015 & 2016 & 2015 & 2016 & 2015 & 2016 & 2015 & 2016 & 2015 & 2016 & 2015 & 2016 \\
\hline Control (unsprayed trees) & 2.1 & 2.3 & 1.0 & 1.0 & 3.1 & 3.3 & 0.9 & 0.9 & \begin{tabular}{|l|}
1.60 \\
\end{tabular} & 1.54 & 0.10 & 0.09 \\
\hline K-silicate at $0.05 \%$ once & 2.4 & 2.6 & 1.3 & 1.3 & 3.7 & 3.9 & 1.2 & 1.3 & 1.67 & 1.60 & 0.13 & 0.12 \\
\hline K-silicate at $0.05 \%$ twice & 2.8 & 3.0 & 1.6 & 1.6 & 4.4 & 4.6 & 1.5 & 1.6 & 1.75 & 1.69 & 0.15 & 0.14 \\
\hline K-silicate at $0.05 \%$ thrice & 2.9 & 3.1 & 1.7 & 1.7 & 4.6 & 4.8 & 1.6 & 1.6 & \begin{tabular}{|l|}
1.77 \\
\end{tabular} & 1.70 & 0.16 & 0.15 \\
\hline K-silicate at $0.1 \%$ once & 3.4 & 3.6 & & 0 & 5.5 & 5.7 & 2.0 & 1.9 & 1.84 & 1.86 & 0.19 & 0.18 \\
\hline K-silicate at $0.1 \%$ twice & 3.9 & 4.0 & 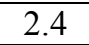 & 2 & 6.3 & 6.5 & 2.3 & 2.2 & 1.91 & 1.94 & 0.22 & 0.21 \\
\hline K-silicate at $0.1 \%$ thrice & 4.0 & .1 & 2.5 & 26 & 6.5 & 6.7 & 2.4 & 2.3 & 1.92 & 1.95 & 0.23 & 0.22 \\
\hline K-silicate at $0.2 \%$ once & 3.5 & 3.7 & 2.2 & 2.2 & 5.7 & 5.9 & 2.1 & 2.0 & 1.85 & 1.87 & 0.20 & 0.19 \\
\hline K-silicate at $0.2 \%$ twice & 4.0 & 4.1 & 2.5 & 2.6 & 6.5 & 6.7 & 2.4 & 2.3 & 1.92 & 1.95 & 0.22 & 0.22 \\
\hline K-silicate at $0.2 \%$ thrice & 4.1 & 4.2 & 2.6 & 2.6 & 6.7 & 6.8 & 2.5 & 2.3 & 1.93 & 1.96 & 0.23 & 0.23 \\
\hline New L.S.D at 5\% & 0.3 & 0.3 & 0.2 & 0.2 & 0.3 & 0.3 & 0.2 & 0.2 & 0.05 & $\mathbf{0 . 0 5}$ & 0.02 & \begin{tabular}{|l|l|}
0.02 \\
\end{tabular} \\
\hline
\end{tabular}

Table 4. Effect of different concentrations and application frequencies of potassium silicate on leaf content of $\mathrm{K}, \mathrm{Mg}, \mathrm{Ca}$ and $\mathrm{S}$ (as \%) and $\mathrm{Zn}$ and $\mathrm{Fe}$ (as ppm) in the leaves of Zaghloul date palms during 2015 and 2016 seasons.

\begin{tabular}{|c|c|c|c|c|c|c|c|c|c|c|c|c|}
\hline \multirow[t]{2}{*}{ Treatment } & \multicolumn{2}{|c|}{$\begin{array}{c}\text { Leaf K } \\
\%\end{array}$} & \multicolumn{2}{|c|}{$\begin{array}{c}\text { Leaf Mg } \\
\%\end{array}$} & \multicolumn{2}{|c|}{$\begin{array}{c}\text { Leaf Ca } \\
\%\end{array}$} & \multicolumn{2}{|c|}{$\begin{array}{c}\text { Leaf } S \\
\%\end{array}$} & \multicolumn{2}{|c|}{$\begin{array}{c}\text { Leaf } \mathrm{Zn} \\
\%\end{array}$} & \multicolumn{2}{|c|}{$\begin{array}{c}\text { Leaf Fe } \\
\%\end{array}$} \\
\hline & 2015 & 2016 & 2015 & 2016 & 2015 & 2016 & 2015 & 2016 & 2015 & 2016 & 2015 & 2016 \\
\hline Control (unsprayed trees) & 0.66 & 0.69 & 0.45 & 0.49 & 1.55 & 1.62 & 0.06 & 0.07 & 150.0 & 149.9 & 84.0 & 86.3 \\
\hline K-silicate at $0.05 \%$ once & 0.73 & 0.74 & 0.49 & 0.53 & 1.63 & 1.70 & 0.11 & 0.12 & 155.0 & 155.9 & 87.0 & 89.0 \\
\hline K-silicate at $0.05 \%$ twice & 0.80 & 0.79 & 0.54 & 0.56 & 1.72 & 1.77 & 0.16 & 0.16 & 161.0 & 160.0 & 91.9 & 92.9 \\
\hline K-silicate at $0.05 \%$ thrice & 0.81 & 0.80 & 0.55 & 0.57 & 1.73 & 1.78 & 0.17 & 0.17 & 162.9 & 160.9 & 92.0 & 93.0 \\
\hline K-silicate at $0.1 \%$ once & 0.91 & 0.87 & 0.61 & 0.62 & 1.81 & 1.86 & 0.22 & 0.23 & 167.0 & 169.0 & 95.9 & 96.0 \\
\hline K-silicate at $0.1 \%$ twice & 0.97 & 0.94 & 0.66 & 0.66 & 1.90 & 1.95 & 0.27 & 0.30 & 171.9 & 173.3 & 99.9 & 98.3 \\
\hline K-silicate at $0.1 \%$ thrice & 0.98 & 0.95 & 0.67 & 0.67 & 1.91 & 1.96 & 0.28 & 0.31 & 172.0 & 173.9 & 101.0 & 99.0 \\
\hline K-silicate at $0.2 \%$ once & 0.92 & 0.88 & 0.62 & 0.63 & 1.82 & 1.87 & 0.23 & 0.24 & 167.6 & 169.3 & 96.0 & 96.1 \\
\hline K-silicate at $0.2 \%$ twice & 0.98 & 0.95 & 0.67 & 0.67 & 1.91 & 1.96 & 0.28 & 0.31 & 172.0 & 173.6 & 100.0 & 98.6 \\
\hline K-silicate at $0.2 \%$ thrice & 0.99 & 0.96 & 0.68 & 0.68 & 1.92 & 1.97 & 0.29 & 0.32 & 172.3 & 174.0 & 101.3 & 99.3 \\
\hline New L.S.D at 5\% & 0.05 & 0.05 & 0.03 & 0.03 & 0.07 & 0.07 & 0.04 & 0.04 & 2.9 & 3.0 & 2.1 & 1.9 \\
\hline
\end{tabular}

Table 5. Effect of different concentrations and application frequencies of potassium silicate on bunch weight, yield and some physical characteristics of the fruits of Zaghloul date palms during 2015 and 2016 seasons.

\begin{tabular}{|c|c|c|c|c|c|c|c|c|c|c|c|c|}
\hline \multirow[t]{2}{*}{ Treatment } & \multicolumn{2}{|c|}{$\begin{array}{l}\text { Bunch weight } \\
\text { (kg.) }\end{array}$} & \multicolumn{2}{|c|}{$\begin{array}{l}\text { Yield/palm } \\
\text { (kg) }\end{array}$} & \multicolumn{2}{|c|}{$\begin{array}{c}\text { Fruit } \\
\text { weight } \\
\text { (g.) }\end{array}$} & \multicolumn{2}{|c|}{$\begin{array}{c}\text { Fruit } \\
\text { height } \\
(\mathrm{cm})\end{array}$} & \multicolumn{2}{|c|}{$\begin{array}{l}\text { Fruit di- } \\
\text { ameter } \\
\text { (cm) }\end{array}$} & \multicolumn{2}{|c|}{$\begin{array}{c}\text { Seed } \\
\text { weight } \\
\%\end{array}$} \\
\hline & 2015 & 2016 & 2015 & 2016 & 2015 & 2016 & 2015 & 2016 & 2015 & 2016 & 2015 & 2016 \\
\hline Control ( & 10 & 10.1 & 108.0 & 101.0 & 20.0 & 19.9 & 5.0 & 4.9 & 2.6 & 2.4 & 18.0 & 18.2 \\
\hline K-silicate at $0.05 \%$ once & 10 & 10.7 & 109.0 & 107.0 & 21.9 & 21.9 & 5.3 & 5.4 & 2.9 & 2.6 & 17.1 & 17.7 \\
\hline K-silicate at $0.05 \%$ twice & .5 & 11.3 & 115.0 & 113.0 & 23.9 & 23.9 & 5.6 & 5.7 & 3.1 & 3.0 & 16.5 & 17.0 \\
\hline K-silicate at $0.05 \%$ thrice & 11.6 & 11.4 & 116.0 & 114.0 & 24.0 & 24.0 & 5.7 & 5.8 & 3.2 & 3.1 & 16.4 & 16.9 \\
\hline K-silicate at $0.1 \%$ once & 12.2 & 12.3 & 122.0 & 123.0 & 25.4 & 25.9 & 6.0 & 6.1 & 3.6 & 3.5 & 16.0 & 16.4 \\
\hline K-silicate at $0.1 \%$ twice & 2.9 & 13.0 & 129.0 & 130.0 & 27.0 & 27.1 & 6.2 & 6.4 & 3.9 & 3.9 & 15.6 & 16.0 \\
\hline K-silicate at $0.1 \%$ thrice & 13.0 & 13.1 & 130.0 & 1.0 & 27.1 & 27. & 6.3 & 6.5 & 4.0 & 4.0 & 15.5 & 15.9 \\
\hline K-silicate at $0.2 \%$ once & 1 & 12.4 & 123.0 & 124.0 & 25.5 & 26.0 & 6.1 & 6.2 & 3.6 & 3.6 & 15.9 & 16.3 \\
\hline K-silicate at $0.2 \%$ twice & 0 & 13.1 & 130.0 & 131.0 & 27.1 & 27.2 & 6.3 & 6.5 & 4.0 & 4.0 & 15.5 & 15.9 \\
\hline K-silicate at $0.2 \%$ thrice & 13.1 & 13.2 & 131.0 & 132.0 & 27.2 & 27.3 & 6.4 & 6.6 & 4.1 & 4.1 & 15.4 & 15.7 \\
\hline New L.S.D at 5\% & 0.5 & 0.5 & 4.0 & 4.0 & 1.1 & 1.2 & 0.2 & 0.2 & 0.02 & $\mathbf{0 . 0 2}$ & 0.04 & $\mathbf{0 . 0 5}$ \\
\hline
\end{tabular}


Table 6. Effect of different concentrations and application frequencies of potassium silicate on some physical and chemical characteristics of the fruits of Zaghloul date palms during 2015 and 2016 seasons.

\begin{tabular}{|c|c|c|c|c|c|c|c|c|c|c|c|c|}
\hline \multirow[t]{2}{*}{ Treatment } & \multicolumn{2}{|c|}{$\begin{array}{c}\text { Pulp } \\
\text { weight } \\
\%\end{array}$} & \multicolumn{2}{|c|}{ Pulp/seed } & \multicolumn{2}{|c|}{$\begin{array}{c}\text { T.S.S. } \\
\%\end{array}$} & \multicolumn{2}{|c|}{$\begin{array}{c}\text { Total sugars } \\
\%\end{array}$} & \multicolumn{2}{|c|}{$\begin{array}{c}\text { Reducing } \\
\text { sugars } \\
\%\end{array}$} & \multicolumn{2}{|c|}{$\begin{array}{c}\text { Non- } \\
\text { reducing } \\
\text { sugars \% }\end{array}$} \\
\hline & 2015 & 2016 & 2015 & 2016 & 2015 & 2016 & 2015 & 2016 & 2015 & 2016 & 2015 & 2016 \\
\hline Con & 82.0 & 81.8 & 46 & & 26.0 & 25.8 & 20.0 & 19.7 & 13.0 & 12.9 & 7.0 & 6.8 \\
\hline K-silit & 82.9 & \begin{tabular}{|l|}
82.3 \\
\end{tabular} & & & 26.9 & 26.3 & 0.6 & 0.4 & 13.4 & 13.4 & 7.2 & 7.0 \\
\hline & 83.5 & 83.0 & & & & 27.3 & 1.0 & 0.8 & 14.0 & 14.1 & 7.0 & 6.7 \\
\hline & 6 & 3.1 & & & 27.2 & 27.4 & & & 14.1 & 14.2 & 7.1 & 6.8 \\
\hline & 84.0 & 83.6 & & 5. & 28.0 & 28.3 & 21.6 & 21.00 & 14.7 & 14.9 & 6.9 & 6.8 \\
\hline & 84.4 & 84.0 & 5. & 5.3 & 28.6 & 29.0 & 22 & 21.7 & 15.3 & 15.5 & 6.7 & 6.6 \\
\hline K-sili & 84.5 & 84.1 & 5.5 & 5.3 & 28.7 & 29.2 & 22.1 & 22.2 & 15.4 & 15.6 & 6.7 & 6.6 \\
\hline K-silicate at $0.2 \%$ once & 84.1 & 83.7 & 5.3 & 5.1 & 28.2 & 28.4 & 21.7 & 21.8 & 14.8 & 15.0 & 6.9 & 6.8 \\
\hline K-silicate at $0.2 \%$ twice & 84.5 & 84.1 & 5.5 & 5.3 & 28.7 & 29.1 & 22.1 & 22.2 & 15.4 & 15.5 & 6.7 & 6.7 \\
\hline K-silicate at $0.2 \%$ thrice & 84.6 & 84.3 & J. & 5. & 28.8 & 29.3 & 22.2 & 22.3 & 15.5 & 15.7 & 6.7 & 6.6 \\
\hline New L.S.D at 5\% & 0.9 & 0.6 & 0.2 & 0.2 & 0.3 & 0.3 & 0.3 & 0.3 & 0.4 & 0.4 & NS & NS \\
\hline
\end{tabular}

Table 7. Effect of different concentrations and application frequencies of potassium silicate on some chemical characteristics of the fruits of Zaghloul date palms during 2015 and 2016 seasons.

\begin{tabular}{|l|c|c|c|c|c|c|}
\hline \multirow{2}{*}{\multicolumn{1}{c|}{ Treatment }} & \multicolumn{2}{|c|}{ Total acidity \% } & \multicolumn{2}{c|}{ Total fibre \% } & \multicolumn{2}{|c|}{ Total soluble tannins \% } \\
\cline { 2 - 7 } & $\mathbf{2 0 1 5}$ & $\mathbf{2 0 1 6}$ & $\mathbf{2 0 1 5}$ & $\mathbf{2 0 1 6}$ & $\mathbf{2 0 1 5}$ & $\mathbf{2 0 1 6}$ \\
\hline Control (unsprayed trees) & 0.503 & 0.509 & 0.89 & 0.91 & 0.80 & 0.82 \\
\hline K-silicate at 0.05 \% once & 0.470 & 0.480 & 0.84 & 0.85 & 0.74 & 0.75 \\
\hline K-silicate at 0.05\% \% twice & 0.441 & 0.458 & 0.80 & 0.79 & 0.68 & 0.69 \\
\hline K-silicate at 0.05 \% thrice & 0.439 & 0.456 & 0.79 & 0.78 & 0.67 & 0.68 \\
\hline K-silicate at 0.1 \% once & 0.411 & 0.433 & 0.71 & 0.70 & 0.60 & 0.59 \\
\hline K-silicate at 0.1 \% twice & 0.383 & 0.415 & 0.64 & 0.64 & 0.55 & 0.54 \\
\hline K-silicate at 0.1 \% thrice & 0.382 & 0.410 & 0.63 & 0.63 & 0.54 & 0.53 \\
\hline K-silicate at 0.2 \% once & 0.410 & 0.431 & 0.70 & 0.69 & 0.59 & 0.58 \\
\hline K-silicate at 0.2 \% twice & 0.382 & 0.414 & 0.63 & 0.63 & 0.54 & 0.54 \\
\hline K-silicate at 0.2 \% thrice & 0.380 & 0.409 & 0.62 & 0.62 & 0.53 & 0.52 \\
\hline New L.S.D at 5\% & $\mathbf{0 . 0 1 8}$ & $\mathbf{0 . 0 1 9}$ & $\mathbf{0 . 0 4}$ & $\mathbf{0 . 0 5}$ & $\mathbf{0 . 0 4}$ & $\mathbf{0 . 0 4}$ \\
\hline
\end{tabular}

\section{References:}

Abdelaal, A.A.M. and Oraby-Mona, M.M (2013): Using silicon for increasing the tolerance mango $\mathrm{cv}$ Ewaise transplants to drought. World Rural Observations 5(2):3640.

Abd El-Wahab, H.A.M. (2015): Response of Succary mango trees to foliar application of silicon and boron. M.Sc. Thesis Fac. of Agric. Minia Univ. Egypt.

Ahmed, F.F. and Morsy, M. H. (1999): A new method formeasuring leaf area in different fruit crops. Minia of Agric. Res. \& Develop. Vol. (19) pp. 97-105.

Alvarez, J. and Datnoff, E. (2001): The economic potential of silicon for integrated management and sustainable rice production. Crop. Prot. 20:53-48.

Al- Wasfy, M.M.M. (2013): Response of Sakkoti date palms tofoliar application of royal jelly, silicon and vitamins B.Nature of Sci. 9(5): 315321.

Aly, A.S.M. (2015): Effect of spraying Balady mandarin trees with silicon and salicylic acid. M.Sc. Thesis Fac. of Agric. Minia Univ. Egypt.

Association of Official Agricultural Chemists (A.O.A.C.) (2000): Official Methods of Analysis (A.O.A.C), $12^{\text {th }}$ Ed., Benjamin 
Franklin Station, Washington D.C., U.S.A. pp.490-510.

Aziz, T.; Gill, M.A. and Rahmatullah, A. (2002): Silicon nutrition and crop production. Pak. J. Agric. Sci. 39(3): 181-187.

Badran, M.A. (2016): Effect of spraying seaweed extracts and silicon yield and fruit quality of Zaghloul date palms grown under sandy soil condition. Assiut J. Agric. Sci. 47 (5): 165-174.

Cottenie,A.; Verloo, M.; Velghe, M. and Camerlynck, R. (1982): Chemical Analysis of Plant and Soil. Ghent, Belgium, Laboratory of Analytical and Agro-chemistry.State Univ. pp. 200-210.

Epstein, E. (1999). Silicon. Annl. Rev. Plant. Physiol. Plant Mol-Bio. 50:641-664.

El- Khawaga, A.S. and Mansour, A.E.A. (2014): Promoting productivity of Washington Navel orange trees by using some crop seed sprout extracts. Silicon and glutathione. Middle East J. of Applied Sci., 4 (3): 779-785.

Gad El-Kareem, M.R. (2012): Improving productivity of Taimour mango trees by using glutatione, silicon and vitamin B. Minia J. of Agric. Res.\& Develop 32 (7): 1105-1121.

Gomez, K. A. and Gomez, A. A. (1984): Statistical Procedures for Agriculture Research, John Wiley and Sons, New York, pp. 130.

Hattori, T; Inanaga, S.; araki, H.; An, P.; Martia, S.; Luxova, M. and Lux, A. (2005): Application of silicon enhanced drought tolerance in Sorgham bicolor. PhysiologiaPlantarum, 123:459-466.

Ibrahim, H.I.M. and Al- Wasfy, M.M. (2014): The promotive impact of using silicon and selenium with potassium and boron on fruiting of Valencia orange trees grown under Minia region conditions. World Rural Observations 6(2):28-36.

Kanto, T. (2002): Research of silicate of improvement of plant defense against pathogens in japan. Abstract of Second Silicon in Agriculture Conference p. 22-26.

Ma, J.F. (2004): Role of silicon in enhancing the resistance of plants to biotic and abiotic stresses. Soil Scr. Plant Nutr.50:11-18.

Ma, J.F. and Takahashi, E. (2002): Soil, Fertilizer and Plant.Silicon Research in Japan. Elsevier Science, Amsterdam, the Netherlands $p$ 1200.

Mahmoud, Kh. M. H. (2016): Response of Baladymandarian trees to foliar application of boron and silicon. Ph.D. Thesis Fac. of Agric. Minia Univ. Egypt.

Marschner, P. (2012). Mineral Nutrition of Higher Plants .Marschner (Ed.) Academic

press. Thirdedition.MineralNutritio n. Yield and Source-Sink Relationships.pp.115-116.Elsevier.

Mengel, K.; Kirkby, E. A.; Kosegarten, H. and appel, T. (2001). Principles of Plant Nutrition. $5^{\text {th }}$ ed Kluwer Academic Publishers. Dordrecht p. 1-311.

Mohamed, M.A.; El- Sayed, M.A. and Abd El- Wahab, H.A.M. (2015). Response of Succary mango trees to foliar application of silicon and boron. World Rural observation 7(2):93-98.

Summer, M.E. (1985). Diagnosis and Recommendation Integrated System (DRIS) as a guide to orchardfertilization. Hort. Abst. 55(8): 7502.

Von-Wettstein, D. (1957). Chlorophyllletale und der submikroskopische Formwechsel der Plastiden. Experimental Cell Research, 12(3): 427-506.

Wilde, S. A.; Corey, R. B.; Layer, J. G. and Voigt, G. K. (1985). Soils and Plant Analysis for Tree Culture. $3^{\text {rd }} \mathrm{Ed}$, Oxford and (BH publishing Co., New Delhi. India, pp. 529 546. 
تأثير السيليكون علي النمو الخضرى والاثمار فى نخيل البلح الزغلول

عمر محمد السيد هيكل

قسم البساتين (فرع الفاكهة)-كلية الزراعة-جامعة دمنهور - مصر

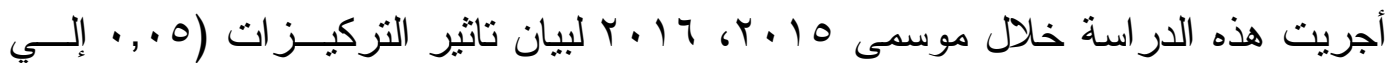

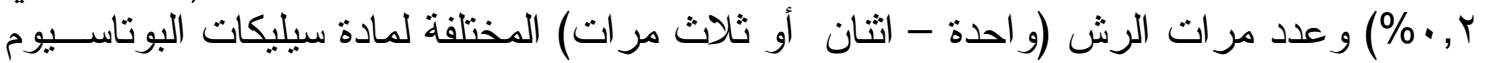

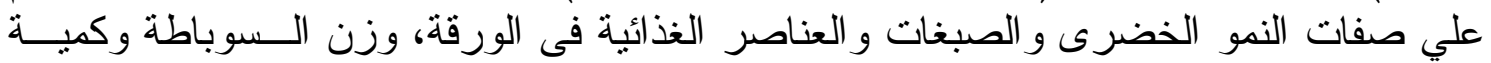

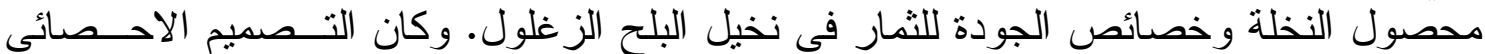

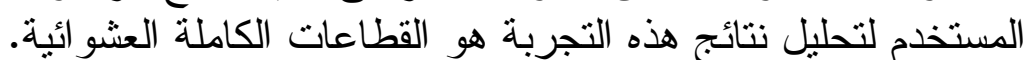

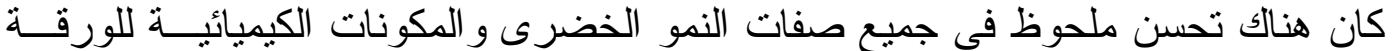

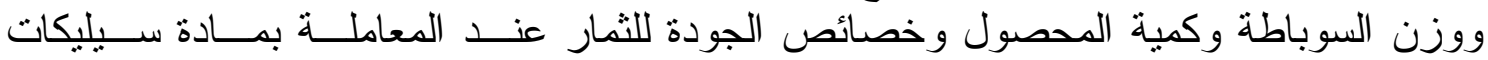

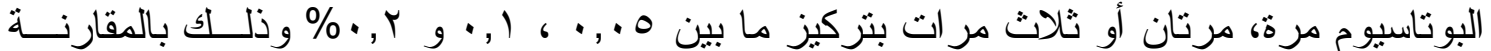

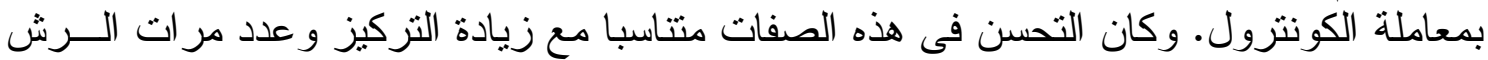

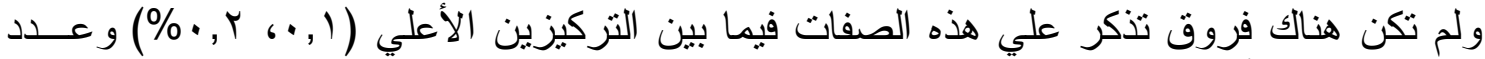
مر ات الرش الأعلي (مرتان وثنات مر مرات).

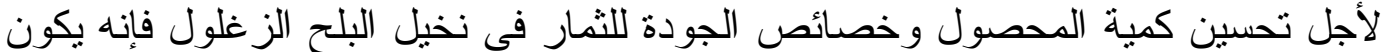

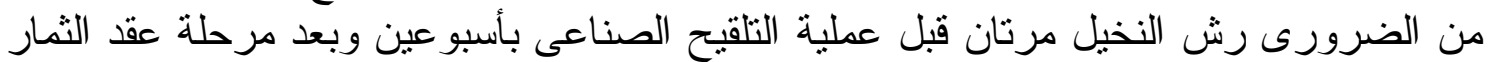

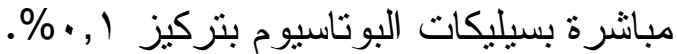

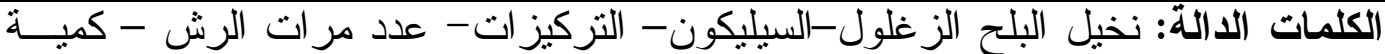

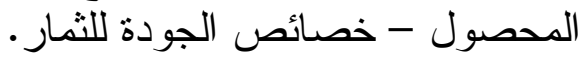

